\title{
DESKRIPSI KEMAMPUAN PEMECAHAN MASALAH MATEMATIS PADA SOAL CERITA BERDASARKAN TIPE KEPRIBADIAN EKSTROVERT-INTROVERT SISWA SMP NEGERI 6 REMBANG
}

\author{
Oleh: \\ Akhmad Jazuli $^{1)}$ dan Muhimmatul Lathifah ${ }^{2)}$ \\ ${ }^{1,2)}$ Program Studi Pendidikan Matematika Universitas Muhammadiyah Purwokerto \\ akhmadjazuli.ump@gmail.com ${ }^{1)}$
}

\begin{abstract}
:
This study aims to describe the ability of mathematical problem solving in solving story problems in terms of the extrovert introvert personality types of SMP N 6 Rembang students on a two-variable linear equation system. This research is a qualitative descriptive study. The subjects in this study were students of class VIIIB SMP $N 6$ Rembang. Selection of Respondents used a purposive sampling technique consisting of three students for each personality type. Data collection techniques using questionnaires, tests, interviews and documentation. Data analysis techniques with data presentation steps, data reduction and conclusions. The results showed that the problem-solving ability for (1) extroverted students: were able to understand the problem and were able to explain again in their own language, were able to draw up a problem-solving plan, were able to carry out calculations and writing very neatly, were able to check the results obtained, (2) introverted students: have been able to understand the problem but have not been able to explain again with their own language, have been able to draw up a problem solving plan and are able to do calculations even though the writing is still messy, in general do not re-check the answers he has obtained.
\end{abstract}

Keywords: Extrovert-Introvert, Problem Solving Ability, Personality Type

\section{PENDAHULUAN}

Matematika merupakan suatu alat untuk mengembangkan cara berfikir, sehingga matematika sangat diperlukan baik untuk kehidupan sehari-hari maupun dalam menghadapi kemajuan ilmu pengetahuan dan teknologi. NCTM (2000) menyebutkan bahwa terdapat 5 ketrampilan proses yang perlu dimiliki siswa melalui pembelajaran matematika yang tercakup dalam standar proses yaitu (1) Pemecahan masalah (problem solving); (2) Penalaran dan pembuktian (reasoning and proof); (3) Komunikasi (communication); (4) Koneksi (connection); dan (5) Representasi (representation). Memnun dkk (2012) berpendapat bahwa kemampuan pemecahan masalah merupakan salah satu kemampuan yang menjadi prioritas utama guna mencapai tujuan pendidikan. Oleh karena itu, salah satu kemampuan matematika yang penting untuk dimiliki oleh siswa yaitu kemampuan pemecahan masalah. Dalam menyelesaikan masalah, siswa diharapkan memahami proses penyelesaian masalah tersebut, menjadi terampil dalam memilih, mengidentifikasikan kondisi dan konsep yang relevan, 


\section{Akhmad Jazuli \& Muhimmatul Lathifah}

Deskripsi Kemampuan Pemecahan Masalah Matematis Pada Soal Cerita Berdasarkan Tipe

Kepribadian Ekstrovert-Introvert Siswa Smp Negeri 6 Rembang

mencari generalisasi, merumuskan rencana penyelesaian dan mengorganisasikan ketrampilan yang telah dimiliki sebelumnya.

Permasalahan dalam kehidupan sehari-hari yang terkait dengan matematika biasanya dituangkan dalam soal cerita. Soal cerita yang terdapat dalam matematika merupakan persoalan-persoalan yang terkait dengan kehidupan sehari-hari yang dapat dicari penyelesaiannya dengan menggunakan kalimat matematika yang memuat operasi-operasi hitung bilangan. Dalam menyelesaikan soal cerita tidak hanya melihat hasil akhirnya saja, tetapi juga melihat proses dalam menyelesaikannya. Siswa diharapkan menyelesaikan soal cerita tahap demi tahap sehingga terlihat alur berpikirnya. Tahapan penyelesaian soal cerita yang dikemukakan oleh Polya (1973) yaitu memahami masalah (understanding the problem), merencanakan pemecahan masalah (devising a plan), melaksanakan rencana pemecahan masalah (carrying out the plan) dan memeriksa kembali solusi yang diperoleh (looking back).

Saat menyelesaikan soal cerita matematika, setiap siswa dimungkinkan mempunyai cara berpikir yang berbeda. Hal ini sebagai akibat dari perbedaan sifat yang dimiliki setiap individu berbeda. Pimta dkk (2009) menyatakan bahwa faktor yang mempengaruhi kemampuan pemecahan soal matematika adalah faktor langsung dan faktor tidak langsung. Faktor tidak langsung yang mempengaruhi adalah motivasi dan kemampuan diri. Motivasi dan kemampuan diri merupakan faktor yang berasal dalam diri siswa sehingga dapat dipengaruhi oleh karakteristik yang dimiliki. Karakteristik tersebut dapat dikatakan sebagai tipe kepribadian siswa. Sedangkan menurut Dewiyani \& Sagirani (2012), "every personality types had different thinking process profil in problem solving." Siswa dengan tipe kepribadian yang berbeda, akan berbeda pula proses berpikirnya dalam memecahkan masalah. Hal tersebut didukung juga dengan pernyataan dari Okike \& Amoo (2014) yang menyatakan bahwa dengan perbedaan kepribadian yang dimiliki seseorang, mereka tidak mungkin memecahkan masalah dengan pendekatan dan pengambilan keputusan yang sama.

Beberapa ahli menggolongkan kepribadian dalam berbagai macam tipe. Salah satunya Carl Gustav Jung yang menggolongkan tipe kepribadian ke dalam dua kelompok besar yaitu tipe kepribadian ekstrovert dan tipe kepribadian introvert (Yusuf, 2011). Secara umum, individu ekstrovert adalah individu yang senang bersosialisasi, memiliki banyak teman, aktif, suka bepergian, memiliki sifat yang ramah tetapi memiliki kesulitan mengontrol gerak hatinya berkenaan dengan agresif dan mudah marah, berperilaku tanpa dipikirkan terlebih dahulu 

serta kurang menuruti kata hati. Dalam mengerjakan sesuatu orang ekstrovert biasanya lebih cepat meskipun tidak sempurna dan kadang-kadang ceroboh. Sedangkan orang-orang introvert cenderung pendiam, termenung, keputusan yang berdasarkan kata hati, serta tindakannya terutama ditentukan oleh faktor subjektif dan penyesuaian dengan dunia luar kurang baik. Dalam mengerjakan sesuatu orang introvert lebih hati-hati dan teliti.

Berdasarkan uraian di atas, mendorong peneliti untuk melakukan penelitian dengan tujuan mendeskripsikan kemampuan pemecahan masalah matematis siswa dalam menyelesaikan soal cerita ditinjau dari tipe kepribadian Ekstrovert-Introvert. di SMP Negeri 6 Rembang.

\section{METODE PENELITIAN}

Jenis penelitian ini adalah penelitian deskriptif kualitatif. Penelitian ini dilaksanakan di SMP Negeri 6 Rembang pada bulan April 2017. Subjek dalam penelitian ini yaitu siswa kelas VIIIB yang terdiri dari 29 siswa. Pengambilan sampel menggunakan teknik purposive sampling. Pemilihan siswa yang akan dijadikan sebagai responden tersebut dilakukan dengan cara melihat tipe kepribadian yang dimiliki oleh siswa berdasarkan hasil kuesioner, untuk tipe kepribadian ekstrovert diambil 3 siswa, dan untuk tipe kepribadian introvert diambil 3 siswa juga. Kuesioner ini diambil dari dokumen Lestari (2016) dengan memodifikasi seperlunya yang terdiri dari 24 butir pertanyaan. Tes pemecahan masalah terdiri dari 4 soal dengan waktu pengerjaan 80 menit. Materi yang digunakan yaitu sistem persamaan linier dua variabel.

Setelah melihat hasil kuesioner dan tes kemampuan pemecahan masalah matematis siswa kemudian peneliti meyakinkan kembali mengenai perilaku siswa yang dijadikan sebagai responden dengan cara mewawancarai guru dan teman sebaya dari responden. Dari hasil wawancara guru dan wawancara teman sebaya dari responden, diperoleh bahwa dari enam siswa yang sudah ditentukan oleh peneliti tiga diantaranya benar-benar memiliki karakteristik tipe kepribadian ekstrovert dan tiga lainnya benar-benar memiliki karakteristik tipe kepribadian introvert.

\section{HASIL DAN PEMBAHASAN}

Kuesioner diberikan pada siswa kelas VIIIB SMP Negeri 6 Rembang pada tanggal 5 April 2017 yang diikuti oleh 29 siswa. Sedangkan tes kemampuan pemecahan masalah matematis 


\section{Akhmad Jazuli \& Muhimmatul Lathifah}

Deskripsi Kemampuan Pemecahan Masalah Matematis Pada Soal Cerita Berdasarkan Tipe

Kepribadian Ekstrovert-Introvert Siswa Smp Negeri 6 Rembang

siswa dilakukan pada tanggal 12 April 2017. Berikut adalah pembahasan mengenai deskripsi kemampuan pemecahan masalah matematis dari masing-masing tipe kepribadian:

\section{Tipe Kepribadian Ekstrovert}

Berdasarkan hasil tes kemampuan pemecahan masalah dan hasil wawancara yang telah dilakukan, maka dapat ditarik kesimpulan bahwa siswa yang memiliki tipe kepribadian ekstrovert pada langkah pertama pemecahan masalah yaitu memahami masalah. Siswa yang memiliki tipe kepribadian ekstrovert mampu memahami masalah, walaupun tidak menuliskan apa yang diketahui dan ditanyakan pada soal secara lengkap, tetapi pada saat wawancara dia mampu menyebutkan hal-hal yang diketahui dan ditanyakan pada soal dengan menggunakan bahasanya sendiri.

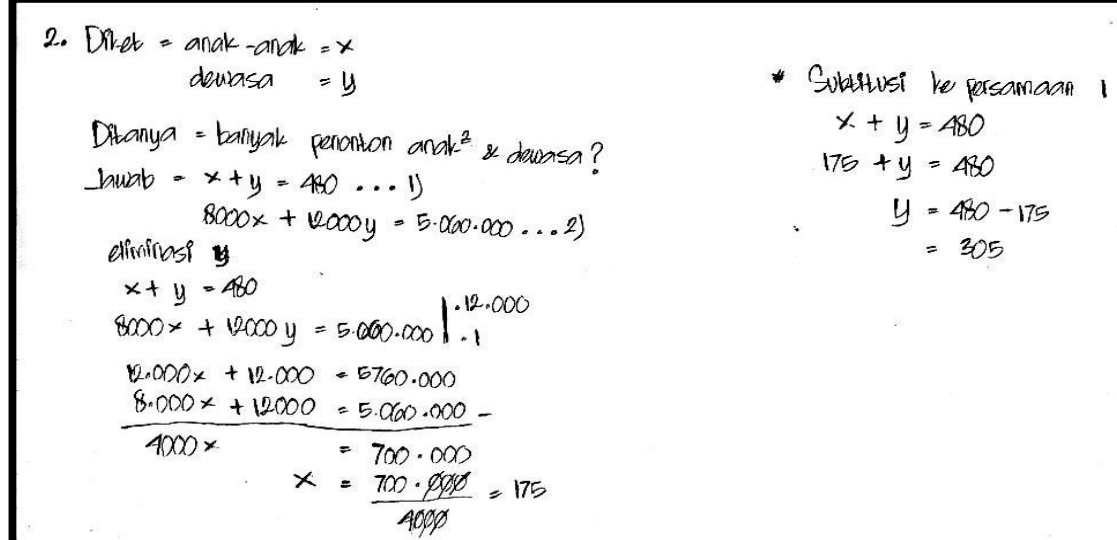

Gambar 1: Contoh Hasil Pekerjaan Siswa Tipe Ekstrovert

Pada langkah kedua pemecahan masalah yaitu membuat rencana pemecahan masalah, siswa yang memiliki tipe kepribadian ekstrovert sudah menyusun rencana hampir untuk semua soal. Namun, dalam terkadang siswa kurang lengkap dalam menuliskan arti variabel-variabel yang sudah dibuatnya. Kemudian pada langkah ketiga yaitu melakukan rencana pemecahan masalah, siswa dengan tipe kepribadian ekstrovert ini sudah melakukannya walaupun terkadang masih kurang teliti pada saat melakukam perhitungan. Siswa sudah mampu menjelaskan kembali jawaban yang sudah ditulisnya dengan bahasa yang komunikatif. Ketika melakukan kesalahan mereka langsung menyadari kesalahannya dan mencoba memperbaiki kesalah tersebut. Selanjutnya pada langkah keempat pemecahan masalah yaitu memeriksa kembali hasil yang diperoleh, siswa dengan tipe kepribadian ekstrovert ini sudah mampu memeriksa kembali jawaban yang sudah diperolehnya dengan cara memeriksa langkah penyelesaian untuk meyakinkan bahwa perhitungan yang dilakukan sudah benar. 
Ditinjau dari tipe kepribadian ekstrovert. Salah satu karakter dari seseorang yang memiliki tipe kepribadian ekstrovert yaitu senang berbicara, sehingga mereka mampu menjelaskan kembali secara lisan hasil jawaban yang sudah mereka tuliskan di lembar jawaban. Karakter yang lainnya yaitu optimis, siswa dengan tipe kepribadian esktrovert ini sangat optimis dengan jawaban yang sudah mereka peroleh. Selain itu, siswa dengan tipe kepribadian ekstrovert ini memiliki percaya diri yang tinggi sehinga pada saat wawancara mereka berani mengemukakan pendapat mereka serta berani mengakui jika ada kesalahan dalam melakukan perhitungan maupun kesalahan dalam penulisan.

\section{Tipe Kepribadian Introvert}

Berdasarkan hasil tes kemampuan pemecahan masalah dan hasil wawancara yang telah dilakukan, maka dapat ditarik kesimpulan bahwa siswa yang memiliki tipe kepribadian introvert pada langkah pertama pemecahan masalah sudah mampu memahami masalah, siswa menuliskan informasi-informasi yang diketahui dari soal dengan langsung mengubah ke dalam model matematikanya tanpa menyertakan pernyataan yang tertulis dalam soal. Pada saat wawancara, dalam menyampaikan hal-hal yang diketahui dan ditanyakan siswa dengan tipe kepribadian introvert ini masih membaca kembali soal yang disajikan, belum menggunakan kalimatnya sendiri. Kemudian pada langkah kedua pemecahan masalah yaitu membuat rencana pemecahan masalah, siswa yang meniliki tipe kepribadian ekstrovert sudah menyusun rencana hampir untuk semua soal.

Pada langkah ketiga yaitu melakukan rencana pemecahan masalah, siswa dengan tipe kepribadian introvert ini sudah melakukannya walaupun terkadang masih kurang teliti pada saat melakukam perhitungan karena pada saat mengerjakan tergesa-gesa. Pada saat menjelaskan kembali langkah penyelesaiannya, siswa dengan tipe kepribadian introvert masih menjelaskan secara singkat bahkan hanya menunjukkan langkah penyelesaiannya. Selanjutnya pada langkah keempat pemecahan masalah yaitu memeriksa kembali hasil yang diperoleh, walaupun mereka masih merasa ragu dengan jawaban yang diperoleh siswa dengan tipe kepribadian introvert ini tidak memeriksa kembali hasil yang sudah diperolehnya. 


\section{Akhmad Jazuli \& Muhimmatul Lathifah}

Deskripsi Kemampuan Pemecahan Masalah Matematis Pada Soal Cerita Berdasarkan Tipe

Kepribadian Ekstrovert-Introvert Siswa Smp Negeri 6 Rembang

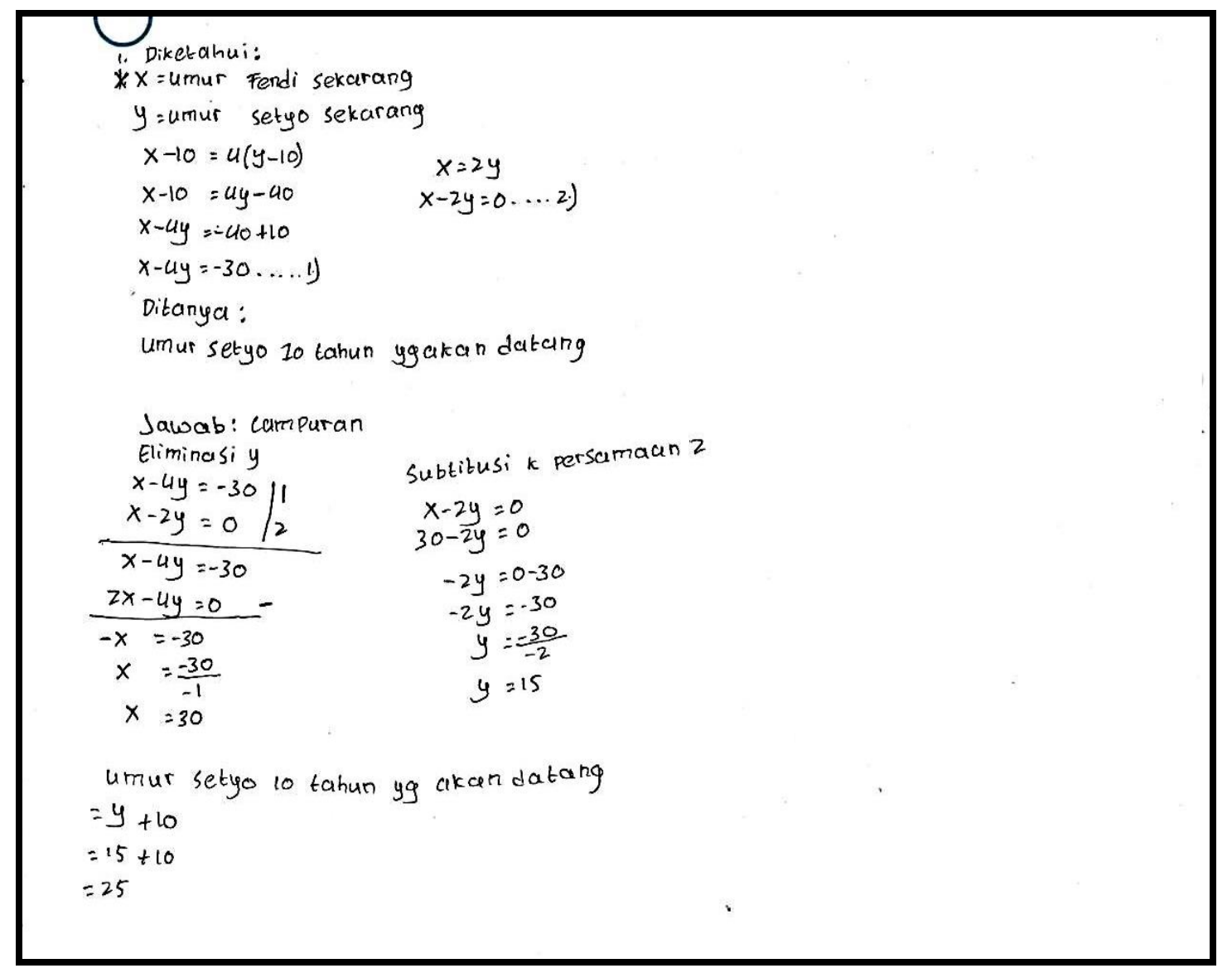

Gambar 2 : Contoh Hasil Pekerjaan Siswa Tipe Introvert

Setelah mengetahui kemampuan pemecahan masalah matematis siswa dengan tipe kepribadian introvert, selanjutnya akan dibahas mengenai deskripsi kemampuan pemecahan masalah matematis siswa kelas VIIIB SMP Negeri 6 Rembang ditinjau dari tipe kepribadian introvert. Salah satu karakter dari seseorang yang memiliki tipe kepribadian introvert yaitu pendiam. Siswa yang memiliki tipe kepribadian introvert dalam menuliskan jwaban masih kurang rapi namun sudah runtut. Siswa tersebut masih kurang mampu menjelaskan kembali hasil jawaban yang sudah mereka tuliskan secara lisan. Karena pada saat wawancara dilakukan siswa yang memiliki tipe kepribadian introvert cenderung lebih terfokus pada lembar jawaban dan belum bisa menjelaskan kembali jawaban dengan menggunakan bahasanya sendiri. Karakter yang selanjutnya yaitu pesimis, siswa yang memiliki tipe kepribadian introvert cenderung pesimis dengan hasil yang mereka peroleh, karena pada saat wawancara jika mereka mengetahui bahwa terdapat kesalahan dalam penulisan maupun perhitungan mereka langsung pesimis dan menilai bahwa jawaban mereka adalah salah. 

Setelah mengetahui deskripsi kemampuan pemecahan masalah matematis siswa dari tipe $\mathrm{k}$ epribadian, berikut perbedaan hasil kemampuan pemecahan masalah matematis siswa dengan tipe kepribadian ekstrovert dan tipe kepribadian introvert:

Tabel 1. Perbedaan Kemampuan Pemecahan Masalah Matematis Siswa dengan Tipe Kepribadian Ekstrovert-Introvert

\begin{tabular}{|c|c|c|c|}
\hline No & $\begin{array}{c}\text { Langkah } \\
\text { Kemampuan } \\
\text { Pemecahan } \\
\text { Masalah }\end{array}$ & $\begin{array}{c}\text { Tipe Kepribadian } \\
\text { Ekstrovert }\end{array}$ & Tipe Kepribadian Introvert \\
\hline 1 & $\begin{array}{r}\text { Memahami } \\
\text { masalah }\end{array}$ & $\begin{array}{l}\text { Belum menuliskan hal-hal } \\
\text { yang diketahui dalam soal } \\
\text { tetapi pada saat wawancara } \\
\text { merekar mampu } \\
\text { menyampaikannya secara } \\
\text { lantang. }\end{array}$ & $\begin{array}{l}\text { Menuliskan hal-hal yang } \\
\text { diketahui dalam soal dengan } \\
\text { langsung membuat model } \\
\text { matematikanya dan pada saat } \\
\text { wawancara siswa hanya } \\
\text { membaca kembali soal yang } \\
\text { disajikan. }\end{array}$ \\
\hline 2 & $\begin{array}{c}\text { Menyusun } \\
\text { rencana } \\
\text { pemecahan } \\
\text { masalah }\end{array}$ & $\begin{array}{l}\text { Sudah mampu membuat } \\
\text { rencana pemecahan masalah } \\
\text { dan mampu menyampaikan } \\
\text { kembali rencana yang telah } \\
\text { dibuatnya. }\end{array}$ & $\begin{array}{lr}\text { Mampu menyusun rencana } \\
\text { pemecahan masalah namun } \\
\text { kurang mampu dalam } \\
\text { menjelaskan kembali } & \text { rencana } \\
\text { yang telah disusunnya. }\end{array}$ \\
\hline 3 & $\begin{array}{c}\text { Melakukan } \\
\text { rencana } \\
\text { pemecahan } \\
\text { masalah }\end{array}$ & $\begin{array}{l}\text { Alur dalam mengerjakannya } \\
\text { sudah terstruktur serta } \\
\text { penulisannya sangat rapi. } \\
\text { Siswa dapat menjelaskan } \\
\text { kembali proses pemecahan } \\
\text { masalah dengan runtut. }\end{array}$ & $\begin{array}{l}\text { Perhitungan sudah runtut tetapi } \\
\text { dalam penulisannya masih } \\
\text { kurang rapi. Kemudian, masih } \\
\text { sangat singkat ketika } \\
\text { menjelaskan kembali proses } \\
\text { pemecahan masalahnya. }\end{array}$ \\
\hline 4 & $\begin{array}{r}\text { Memeriksa } \\
\text { kembali }\end{array}$ & $\begin{array}{l}\text { Memeriksa kembali hasil } \\
\text { yang telah diperoleh dengan } \\
\text { cara memeriksa kembali } \\
\text { langkah-langkah }\end{array}$ & $\begin{array}{l}\text { Walaupun masih ragu-ragu } \\
\text { dengan jawabannya, subjek } \\
\text { tidak memeriksa kembali hasil } \\
\text { yang diperoleh. }\end{array}$ \\
\hline
\end{tabular}




\section{Akhmad Jazuli \& Muhimmatul Lathifah}

Deskripsi Kemampuan Pemecahan Masalah Matematis Pada Soal Cerita Berdasarkan Tipe

Kepribadian Ekstrovert-Introvert Siswa Smp Negeri 6 Rembang

penelesaiannya.

\section{SIMPULAN}

Berdasarkan hasil penelitian pengembangan dan, dapat disimpulkan bahwa: 1) Siswa dengan dengan tipe kepribadian ekstrovert pada saat memahami permasalahan mampu menyampaikan dengan menggunakan bahasanya sendiri, walaupun belum menuliskan dalam lembar jawabannya. Siswa mampu menuliskan model matematika sebagai rencana penyelesaian masalah. Siswa mampu menjelaskan kembali dengan lancar cara pemecahan masalahnya secara lisan dengan baik serta penulisannya sangat rapi. Siswa mampu memeriksa prosedur penyelesaian yang telah dilakukan dengan memeriksa setiap langkah yang telah dilalui namun tidak menuliskan kembali untuk memeriksa kebenaran jawaban, 2) Siswa dengan tipe kepribadian introvert pada saat memahami masalah belum mampu menyampaikan dengan menggunakan bahasanya sendiri dan masih membaca soal yang disajikan. Siswa sudah mampu membuat rencana pemecahan masalah untuk menyelesaikan permasalahan yang disajikan. Dalam menjelaskan kembali langkah penyelesaian, siswa masih sangat singkat bahkan hanya menunjukkan penyelesaian yang sudah ditulisnya dan penulisannya masih berantakan. Siswa belum mampu memeriksa kembali jawaban yang sudah diperolehnya.

\section{DAFTAR PUSTAKA}

Adjie dan Maulana. (2006). Pemecahan Masalah Matematika.Bandung: UPI

Dewiyani , M.J. dan Sagirani, T. (2012).The Thinking Process Profile The Students of Informatics System Departement in Solving The Mathematics Problem Based on The Personality Type and Gender. Proceeing hal 1-10.STIKOM Surabaya.

Feist, J \& Feist, G.J. (2013). Teori Kepribadian. Jakarta:Salemba Humanika

Hasanah, N dkk. (2011). Analisis Proses Berpikir Siswa Dalam Memecahkan Masalah Matematika Ditinjau Dari Tipe Kepribadian Ekstrovert-Introvert Dan Gender. PPs Universitas Sebelas Maret: Prodi Magister Pendidikan Matematika

Harmini, Winarni. (2012). Matematika untuk PGSD. Bandung: Rosda

Lestari, S.W. (2016). “Analisis Proses Berpikir Kritis Siswa Dalam Pemecahan Masalah Matematika Pada Pokok Bahasan Himpunan Ditinjau Dari Tipe Kepribadian Ekstrovert Dan Introvert Siswa Kelas VII SMPN 2 Sumber Cirebon", Skripsi, Semarang:Fakultas Sains dan Teknologi Universitas Islam Negeri Walisongo.

Memnun, D.S dkk. (2012). "A Research on Mathematical Problem Solving Beliefs of Mathematics, Science and Elementary Pre-Service Teachers in Turkey interms of 
Different Variables". International Journal of Humanities and Social Science, 2, (24), 172-184

Miles, M.B \& Huberman,A. M. (1992). Analisis Data Kualitatif. Terjemahan oleh Tjetjep Rohadi Rohidi. Jakarta: Universitas Indonesia Press.

Moleong, Lexy J. (2013). Metodologi Penelitian Kualitatif. Bandung : PT Remaja Rosdakarya

Nasution, S. (2010). Berbagai Pendekatan dalam Proses Belajar dan Mengajar. Jakarta: Pt Bumi Aksara

NCTM. (2000). Principles and Standards for School Mathematics. Reston, VA: NCTM

Okike, Ezekiel U dan Olanrewaju AA. (2012). "Problem Solving and Decision: Consideration of Individual Differences in Computer Programming Skills Using Myers Brriggs Type Indicator (MBTI) and Chidamber and Kemerer Java Metrics".Departement of Computer Science, University of Botswana.

Permendiknas Nomor 22 Tahun 2006. Jakarta: Pemerintah RI.

Pimta, S dkk. (2009). "Factors Influencing Mathematic Problem Solving Ability of Sixth Grade Students". Journal of Social Sciences. 5, (4), 381-385

Pervin, L.A dkk. (2004). Psikologi Kepribadian. Jakarta: Prenadamedia Group

Polya, G. (1973). How To Solve It : A New Aspect of Mathematical Method. Princeton, New Jersey. Princeton University Press.

Rahardjo dan Waluyati. (2011). Pembelajaran Soal Cerita Operasi Hitung di SD. Yogyakarta: Pusat Pengembangan dan Pemberdayaan Pendidik dan Tenaga Kependidikan Matematika.

Shadiq. Fadjar. (2014). Belajar Memecahkan Masalah Matematika. Yogyakarta: Graha Ilmu Solso, R.L dkk. (2007). Psikologi Kognitif. Jakarta:Erlangga

Sugiyono. (2013). Metode Penelitian Pendidikan. Bandung : Alfabeta

Undang-undang Republik Indonesia Nomor 20 Tahun 2003 tentang Sistem Pendidikan Nasional.

Walgito, Bimo. (1980). Pengantar Psikologi Umum. Yogyakarta: CV Andi Offset

Wena, Made. (2011). Strategi Pembelajaran Inovatif Kontemporer :Suatu Tinjauan Konseptual Operasional. Jakarta : PT Bumi Aksara

Widayanti, L. (2016). "Deskripsi Level Kemampuan Siswa Dengan Tipe Kepribadian Cenderung Introvert Dalam Menyelesaikan Masalah Matematika”. Jurnal Edukasi, 2, (1). 83-94

Yusuf, S dan Nurihsan, J. (2011). Teori Kepribadian. Bandung: PT Remaja Rosdakarya 


\section{Akhmad Jazuli \& Muhimmatul Lathifah}

Deskripsi Kemampuan Pemecahan Masalah Matematis Pada Soal Cerita Berdasarkan Tipe Kepribadian Ekstrovert-Introvert Siswa Smp Negeri 6 Rembang

Zhu, Zheng. (2007). "Gender Differences in Mathematical Problem Solving Patterns: A Review of Literature”. International Education Journal, 8, (2), 187-203 